\title{
ВПРОВАДЖЕННЯ В УКРАЇНІ ОНОВЛЕНОЇ СИСТЕМИ ІНДИКАТОРІВ РАННЬОГО ЗАПОБІГАННЯ МЕДИКАМЕНТОЗНІЙ РЕЗИСТЕНТНОСТІ ВІЛ
}

\author{
ДУ «Інститут епідеміології та інфекційних хвороб ім. Л.В. Громашевського НАМН України», \\ ДУ «Центр громадського здоров'я МОЗ України»
}

Проведено одномоментні (поперечні) дослідження ретроспективно зібраних даних з 22 центрів СНІДу, які надають антиретровірусну терапію (АРТ) ВІЛінфрікованим дорослим і дітям.

мета роботи - оцінити показники роботи закладів щодо ефрективності фрормування у пацієнта прихильності до лікування (своєчасність отримання пацієнтом антиретровірусних препаратів (АРВП), а також щодо якості виконання програмних фракторів (утримання пацієнтів під диспансерним наглядом, безперервність поставок АРВП, практика призначення моно- або бітерапії, максимальна вірусна супресія ВІЛ).

матеріали і методи. Дані проаналізовані за допомогою електронного інструменту, розробленого Всесвітньою організацією охорони здоров'я (ВООЗ) індикаторів раннього запобігання (IP3) медикаментозній резистентності (MP) ВІЛ.

Результати. Встановлено, що в 2014-2015 рр. ВІЛ-інфіковані дорослі пацієнти своєчасно отримували АРВП тільки в 22,7 \% центрів СНІДу, діти - у 36,4 \% центрів. Утримати під наглядом більше $85 \%$ пацієнтів вдалося 36,4 \% чентрів. У 9,1 \% закладів зафіксовано десріцит АРВП для дорослих пацієнтів, у 4,5 \% - для дітей. Досягнуто максимальної вірусної супресії ВІЛ у дітей в 31,8 \% закладів; по дорослим пацієнтам жодний центр СНІДу не зміг досягти цільового показника.

Висновок. Впровадження щорічного збору та аналізу IPЗ в Україні допоможе своєчасно виявляти та вирішувати проблемні питання в системі надання послуг із АРТ, асоційовані з ризиком фрормування МР ВІЛ, як на рівні окремих закладів, так і на національному рівні.

Ключові слова: індикатори раннього запобігання резистентності ВІЛ (IP3), антиретровірусна терапія (APT), медикаментозна резистентність ВІЛ (МР ВІЛ).

Сучасна ситуація з ВІЛ-інфекції в Україні залишається напруженою, оскільки епідемія продовжує поши- рюватися серед загального населення. За офріційними даними, в Україні станом на 01.01.2016 року зареєстровано 126604 випадки ВІЛ-інфекції (показник 297,2 на 100 тис. нас.), у тому числі 34016 хворих на СНІД (показник 79,8 на 100 тис. нас.) [1].

У відповідь на епідемію розширюються масштаби антиретровірусної терапії. Станом на 01.01.2016 р. у нашій країні отримувало АРТ 60753 ВІЛ-інфріковані особи. Загальнодержавна цільова соціальна програма протидії ВІЛ-інфекції/СНІДу на 2014-2018 рр., затверджена Законом України від 20 жовтня 2014 р. № 1708-VII, передбачає подальше розширення програми АРТ із охопленням близько 118000 пацієнтів до кінця 2018 р.

Розширення масштабів АРТ, з одного боку, дозволяє знизити рівень захворюваності на ВІЛ-інсрекцію/СНІД, з іншого - може призвести до збільшення частоти фрормування та циркуляції серед населення резистентних штамів ВІЛ [2].

Процес розвитку медикаментозної резистентності (MP) ВІЛ до АРВ-препаратів залежить від багатьох фракторів, основними 3 яких є: 1) особливості, пов'язані 3 організмом людини (стан імунітету, генетичні особливості, прихильність до лікування); 2) особливості вірусу (висока реплікативна активність ВІЛ та його висока мінливість); 3) фрармакологічні особливості (фрармакокінетика та генетичний бар'єр АРВП, які застосовують для лікування ВІЛ-інфрікованих пацієнтів).

Не менш важливим виявився ще один фрактор: якість надання послуг з АРТ в центрах профрілактики і боротьби зі СНІДом (центри СНІДу) - закладах охорони здоров'я (3О3), які надають спеціалізовану допомогу ВІЛ-інфрікованим пацієнтам. Цілком зрозуміло, що якщо в таких 303 існує значний дефріцит АРВ-препаратів, практикується призначення АРВП у вигляді моно- або бітерапії (замість комплексної терапії трьома АРВП); якщо прихильність пацієнтів до АРТ (дотримання ними режиму прийому ліків) знаходиться на неприпустимо 
низькому рівні, в цих випадках існує небезпека розвитку МР ВІЛ.

3 метою оцінки еорективності роботи регіональних центрів СНІДу з точки зору якості надання послуг з АРТ, у 2009 році нами було проведено збір та аналіз індикаторів раннього запобігання - спеціального електронного інструменту у фрорматі Excel (HIV DRUG RESISTANCE EARLY WARNING INDICATORS), розробленого Всесвітньою організацією охорони здоров'я (ВОО3) [3]. Отримані тоді результати дозволили зробити висновок, що 3 точки зору запобігання медикаментозній резистентності ВІЛ, система надання медичної допомоги ВІЛінфрікованим пацієнтам потребує удосконалення, оскільки за більшістю показників не було досягнуто цільового рівня [4].

У 2012 р. ВООЗ розробила оновлену версію електронного інструменту із дещо зміненим переліком індикаторів $[5,6]$. Згідно з оновленою версією, ефективність програми надання АРТ (продуктивність роботи закладів) оцінюється за допомогою системи показників декількох кольорів: зеленого («відмінна» продуктивність, досягнення бажаного рівня), бурштинового («помірна» продуктивність, але не на бажаному рівні), червоного («низька» продуктивність, нижче необхідного рівня). Цільовим показником для кожного IP3 є індикатор зеленого кольору. Проблеми з досягненням рівня цільового показника по IP3 можуть означати, що закладам необхідна більш широка підтримка у вигляді додаткових ресурсів, навчання персоналу, збільшення кількості фахівців тощо.

В Україні у 2013 р. розроблено Національну стратегію моніторингу резистентності ВІЛ до АРВ-препаратів, яка обґрунтовує, в тому числі, важливість аналізу IP3 та передбачає проведення щорічного їх збору для оцінки ефективності програм АРТ та застосування заходів щодо усунення виявлених недоліків як на рівні окремих закладів, так і на національному рівні.

Метою нашої роботи було: оцінити ефективність програм надання послуг з АРТ в Україні на рівні спеці- алізованих закладів охорони здоров'я з точки зору їх організаційної здатності щодо запобігання розвитку МР ВІЛ.

\section{Матеріали і методи}

Дослідження проводили в рамках наукового співробітництва між ДУ «Інститут епідеміології та інфекційних хвороб ім. Л.В. Громашевського НАМН України» та ДУ «Український центр контролю за соцхворобами МОЗ України» за фрінансової і технічної підтримки ВООЗ та Федерального агентства «Центри контролю та профрілактики захворювань США» (CDC).

Проведено одномоментне (поперечне) дослідження ретроспективно зібраних даних з 22-х центрів СНІДу (21 обласного та Київського міського). Залучені для збору інформації спеціалізовані 303 характеризувалися зручним географрічним розташуванням, доступністю даних для збору інформації, наявністю підготовлених для збору інфрормації фрахівців. Усі 22 центри СНІДу надавали послуги з АРТ ВІЛ-інфікованим дорослим та дітям.

Розмір вибірки для кожного 303 залежав від кількості ВІЛ-інфікованих пацієнтів на АРТ у конкретному закладі та був розрахований відповідно до керівних вказівок ВООЗ [5-7]. Цільовою групою стали ВІЛ-інфріковані пацієнти, які 3 1 січня 2014 р. розпочали АРТ та не менш 15 міс. знаходилися на лікуванні. Дані вносилися в електронний документ, поки кожним 303 не накопичувалася кількість, необхідна для вибірки. В якості джерел інформації використовувалися: медична карта амбулаторного хворого (форма № 025/0); контрольна карта диспансерного хворого (форма № 0305/0); журнал обліку лікарських засобів, молочних сумішей у відділеннях і кабінетах лікувально-профілактичних закладів, що надають медичну допомогу ВІЛ-інфрікованим (фрорма № 510-1/0).

Загалом у 22-х центрах СНІДу було зібрано та проаналізовано дані 2899 історій хвороб ВІЛ-інфікованих пацієнтів: 2804 дорослих осіб та 95 дітей (табл. 1).

У рамках дослідження проведено збір 5 IP3, рекомендованих ВООЗ (табл. 2).

Таблиця 1

Перелік 303 і розмір вибірки по кожному закладу

\begin{tabular}{|c|c|c|c|c|}
\hline \multirow{2}{*}{ № } & \multirow{2}{*}{ Назва 303} & \multicolumn{3}{|c|}{ Розмір вибірки } \\
\hline & & дорослі пацієнти & діти & загалом \\
\hline 1 & 2 & 3 & 4 & 5 \\
\hline 1. & Вінницький обласний центр СНІДу & 138 & 3 & 141 \\
\hline 2. & Волинський обласний центр СНІДу & 135 & 2 & 137 \\
\hline 3. & Дніпропетровський обласний центр СНІДу & 127 & 9 & 136 \\
\hline 4. & Житомирський обласний центр СНІДу & 148 & 0 & 148 \\
\hline 5. & Закарпатський обласний центр СНІДу & 54 & 2 & 56 \\
\hline
\end{tabular}


ОРИГІНАЛЬНІ ДОСЛІДЖЕННЯ

Продовження табл. 1

\begin{tabular}{|c|c|c|c|c|}
\hline 1 & 2 & 3 & 4 & 5 \\
\hline 6. & Запорізький обласний центр СНІДу & 124 & 0 & 124 \\
\hline 7. & Івано-Франківський обласний центр СНІДу & 130 & 0 & 130 \\
\hline 8. & Київський обласний центр СНІДу & 160 & 5 & 165 \\
\hline 9. & Кіровоградський обласний центр СНІДу & 129 & 14 & 143 \\
\hline 10. & Львівський обласний центр СНІДу & 127 & 1 & 128 \\
\hline 11. & Миколаївський обласний центр СНІДу & 166 & 4 & 170 \\
\hline 12. & Одеський обласний центр СНІДу & 141 & 19 & 160 \\
\hline 13. & Полтавський обласний центр СНІДу & 139 & 4 & 143 \\
\hline 14. & Рівненський обласний центр СНІДу & 111 & 3 & 114 \\
\hline 15. & Сумський обласний центр СНІДу & 107 & 3 & 110 \\
\hline 16. & Харківський обласний центр СНІДу & 135 & 5 & 140 \\
\hline 17. & Херсонський обласний центр СНІДу & 152 & 3 & 155 \\
\hline 18. & Хмельницький обласний центр СНІДу & 131 & 0 & 131 \\
\hline 19. & Черкаський обласний центр СНІДу & 116 & 2 & 118 \\
\hline 20. & Чернівецький обласний центр СНІДу & 46 & 0 & 46 \\
\hline 21. & Чернігівський обласний центр СНІДу & 153 & 1 & 154 \\
\hline 22. & Київський міський центр СНІДу & 161 & 15 & 176 \\
\hline \multicolumn{2}{|r|}{ Всього } & 2830 & 95 & 2925 \\
\hline
\end{tabular}

Примітка. Планувався збір даних з 24-х регіонів, проте з Донецькою областю виявилися певні складнощі, оскільки основна частина пацієнтів залишилася на непідконтрольній території АТО, а в Маріупольському та Слов'янському міських центрах СНІДу серед пацієнтів, які почали АРТ у 2014 р., не нарахували достатньої кількості пацієнтів для забезпечення необхідної вибірки. По причині недостатньої вибірки у моніторингу IP3 не брав участь також Тернопільський обласний центр СНІДу.

Таблиця 2

Перелік зібраних Р3І

\begin{tabular}{|c|c|c|c|}
\hline $\begin{array}{c}\text { Назва індикатора } \\
\text { раннього } \\
\text { застереження (IP3) }\end{array}$ & Визначення IP3 & $\begin{array}{c}\text { Складові розрахунків кольорових } \\
\text { показників IP3 } \\
\text { (чисельник/знаменник) }\end{array}$ & $\begin{array}{c}\text { Значення } \\
\text { кольорових } \\
\text { показників }\end{array}$ \\
\hline 1 & 2 & 3 & 4 \\
\hline $\begin{array}{l}\text { IP3 1. Своєчасність } \\
\text { отримання АРB- } \\
\text { препаратів }\end{array}$ & $\begin{array}{l}\text { Відсоток пацієнтів } \\
\text { цільової групи } \\
\text { (дорослих та дітей), які } \\
\text { отримували АРВ- } \\
\text { препарати своєчасно } \\
\text { або із запізненням не } \\
\text { більше двох днів }\end{array}$ & $\begin{array}{l}\text { Чисельник: Кількість пацієнтів, які своєчасно } \\
\text { отримували АРВ-препарати при першому } \\
\text { візиті після отримання препаратів базової лінії. } \\
\text { Знаменник: кількість пацієнтів, які приймали } \\
\text { АРТ у зазначений період після початку дати } \\
\text { збору IP3. }\end{array}$ & $\begin{array}{l}\text { Зелений: >90 \% } \\
\text { Бурштиновий: } \\
80-90 \text { \% } \\
\text { Червоний: <80 \% }\end{array}$ \\
\hline $\begin{array}{l}\text { IP3 2. Утримання } \\
\text { пацієнта під } \\
\text { наглядом після } \\
12 \text { міс. АРТ }\end{array}$ & $\begin{array}{l}\text { Відсоток пацієнтів } \\
\text { цільової групи } \\
\text { (дорослих та дітей), у } \\
\text { відношенні яких відомо, } \\
\text { що вони живі та } \\
\text { отримують АРТ } \\
\text { протягом } 12 \text { міс. після } \\
\text { початку лікування }\end{array}$ & $\begin{array}{l}\text { Чисельник: Кількість дорослих і дітей, у } \\
\text { відношенні яких було відомо, що вони живі і } \\
\text { продовжують АРТ через } 12 \text { міс. після початку } \\
\text { лікування. } \\
\text { Знаменник: Загальне число дорослих і дітей, } \\
\text { які почали АРТ, у тому числі тих, хто помер } \\
\text { після початку терапії, і тих, хто припинив } \\
\text { терапію, а також тих, хто реєструються як } \\
\text { втрачені для подальшого спостереження до } \\
\text { строку } 12 \text { міс. з початку АРТ. }\end{array}$ & $\begin{array}{l}\text { Зелений: >85 \% } \\
\text { Бурштиновий: } \\
75-85 \text { \% } \\
\text { Червоний: <75 \% }\end{array}$ \\
\hline
\end{tabular}


ОРИГІНАЛЬНІ ДОСЛІДЖЕННЯ

Продовження табл. 2

\begin{tabular}{|c|c|c|c|}
\hline 1 & 2 & 3 & 4 \\
\hline $\begin{array}{l}\text { IP3 3. Безперерв- } \\
\text { ність постачання } \\
\text { антиретровірусних } \\
\text { препаратів }\end{array}$ & $\begin{array}{l}\text { Відсоток місяців у } \\
\text { вибраному проміжку } \\
\text { часу, протягом якого не } \\
\text { було дефіциту АРВ- } \\
\text { препаратів }\end{array}$ & $\begin{array}{l}\text { Чисельник: кількість місяців у зазначеному } \\
\text { році, коли не було дефіциту запасів АРВ- } \\
\text { препаратів, які зазвичай використовуються в } \\
\text { даному закладі. } \\
\text { Знаменник: } 12 \text { міс. }\end{array}$ & $\begin{array}{l}\text { Зелений: } 100 \text { \% } \\
\text { Червоний: <100 \% }\end{array}$ \\
\hline $\begin{array}{l}\text { IP3 4. Практика } \\
\text { призначення } \\
\text { моно- або бітерапії }\end{array}$ & $\begin{array}{l}\text { Відсоток пацієнтів } \\
\text { цільової групи } \\
\text { (дорослих та дітей), які } \\
\text { отримували АРТ у } \\
\text { вигляді одного або двох } \\
\text { АРВ-препаратів }\end{array}$ & $\begin{array}{l}\text { Чисельник: Кількість пацієнтів, в яких схема } \\
\text { АРТ складалася з одного або двох АРВ- } \\
\text { препаратів. } \\
\text { Знаменник: кількість пацієнтів, які приймали } \\
\text { АРТ у зазначений період після початку дати } \\
\text { збору РЗІ. }\end{array}$ & $\begin{array}{l}\text { Зелений: } 0 \text { \% } \\
\text { Червоний: >0 \% }\end{array}$ \\
\hline $\begin{array}{l}\text { IP3 5. Вірусологічна } \\
\text { супресія - пригні- } \\
\text { чення вірусного } \\
\text { навантаження } \\
\text { через } 12 \text { міс. АРТ }\end{array}$ & $\begin{array}{l}\text { Відсоток дорослих } \\
\text { пацієнтів цільової групи, } \\
\text { які через } 12 \text { міс. АРТ } \\
\text { мали рівень вірусного } \\
\text { навантаження менше } \\
1000 \text { РНК-копій/мл }\end{array}$ & $\begin{array}{l}\text { Чисельник: Кількість пацієнтів, які через } \\
12 \text { міс. АРТ мали рівень вірусного } \\
\text { навантаження <1000 РНК-копій/мл. } \\
\text { Знаменник: кількість пацієнтів, які приймали } \\
\text { АРТ у зазначений період після початку дати } \\
\text { збору IP3. }\end{array}$ & $\begin{array}{l}\text { Зелений: >85 \%; } \\
\text { Бурштиновий: } \\
\text { 70-85 \%; } \\
\text { Червоний: <70 \% }\end{array}$ \\
\hline
\end{tabular}

Слід відзначити, що в 5 закладах (Житомирському, Запорізькому, Івано-Франківському, Хмельницькому, Чернівецькому обласних центрах СНІДу) серед пацієнтів, які розпочали антиретровірусну терапію в 2014 р., дітей не було, тому зібрати по них необхідну інформацію виявилося неможливим. По цих закладах відповідний індикатор позначався сірим кольором, оскільки його продуктивність не була класифрікована [5-7].

Для аналізу IP3 3 (безперервність постачання антиретровірусних препаратів) збиралися дані за 12 міс. 2015 р.

\section{Результати досліджень та їх обговорення}

Узагальнені результати аналізу IP3 наведено у таблиці 3.

Отримані результати свідчили, що в 2014-2015 рр. в Україні в більшості регіональних центрів профрілактики і боротьби зі СНІДом не було випадків призначення ВІЛінорікованим пацієнтам моно- або бітерапії (IP3 4), що є ефективним з точки зору запобігання медикаментозній резистентності ВІЛ.

Разом з тим, в деяких 303 зафріксовано дефріцит APB-препаратів (IP3 3). Так, в Запорізькому обласному центрі СНІДу з січня по липень 2015 р. спостерігався десріцит препарату діданозин (ddl 400); в Київському міському центрі СНІДу протягом квітня-травня 2015 р. був відсутнім препарат AZT/3TC; у вересні 2015 р. - препарат TDF/FTC; у листопаді 2015 р. - RTV; у березні та жовтні 2015 р. - ETR (загалом зафіксовано дефіцит APB-препаратів протягом 6 міс. 3 12). В Київському міському центрі СНІДу спостерігався також дефіцит дитячих фрорм АРВП: АВС - з серпня по грудень 2015 р.; ЗТС - у січні 2015 р.; AZT - 3 травня по липень 2015 р.;
NVP - у липні 2015 р. (загалом дефіцит дитячих фрорм спостерігався протягом 10 міс. 3 12). Більш детальний аналіз даних дозволив встановити, що в Україні протягом 2015 р. в окремих регіонах також спостерігався дефріцит тих чи інших APB-препаратів, проте не всі заклади наважилися афрішувати вказані проблеми (тобто електронні форми повинні перевірятися під час заповнення, щоб зроблені по них висновки були корисними). Слід зазначити, що дефріцит антиретровірусних препаратів може бути наслідком як неякісного планування закупівель лікарських засобів у конкретному закладі, так і наслідком недосконалої практики державних закупівель лікарських засобів у цілому по Україні. Десріцит ліків на складах не завжди означає, що пацієнтам не було чим лікуватися, адже вони під час візиту до лікувального закладу отримують кількість препаратів, розраховану на кілька тижнів лікування, проте відсутність АРВ-препаратів може все ж таки призводити до перерв у лікуванні та підвищувати ризик формування МP ВІЛ.

Дещо гірша ситуація з утриманням пацієнтів під наглядом (IP3 2), оскільки цільового показнику (більше 85 \% пацієнтів під наглядом через 12 міс. АРТ) досягли тільки 8 закладів з 22 (36,4 \%); половина закладів (11 3 22) через 12 міс. лікування нарахували від 75 до $85 \%$ пацієнтів, решта 303 (3 з 22) - утримали на терапії менше 75 \% пацієнтів. Це також вагомий фрактор ризику фрормування резистентності ВІЛ, оскільки свідчить про низьку прихильність пацієнта до лікування.

ще більш напруженою виявилася ситуація з IP3 1 (своєчасність отримання АРВ-препаратів), оскільки майже в половині закладів (у 10322 - 45,5 \%) вчасно отримувало АРВ-препарати менше 80 \% дорослих па- 
ОРИГІНАЛЬНІ ДОСЛІДЖЕННЯ

Таблиця 3

Результати аналізу IP3, зібраних у 2016 р. в Україні

\begin{tabular}{|c|c|c|c|c|c|}
\hline \multirow{2}{*}{$\begin{array}{c}\text { Назва індикатора } \\
\text { раннього } \\
\text { запобігання (IP3) }\end{array}$} & \multirow[t]{2}{*}{$\begin{array}{c}\text { Значення кольорових } \\
\text { показників }\end{array}$} & \multicolumn{2}{|c|}{$\begin{array}{c}\text { Кількість 3О3, продуктивність } \\
\text { роботи яких відповідала } \\
\text { кольоровому показнику / загальна } \\
\text { кількість } 303 \text { у дослідженні (\%) }\end{array}$} & \multicolumn{2}{|c|}{ 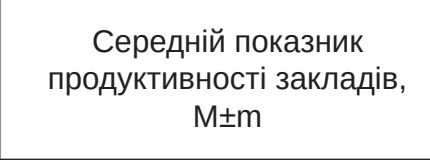 } \\
\hline & & дорослі пацієнти & діти & $\begin{array}{l}\text { для дорослих } \\
\text { пацієнтів }\end{array}$ & для дітей \\
\hline $\begin{array}{l}\text { IP3 1. Своєчасне } \\
\text { отримання АРB- } \\
\text { препаратів }\end{array}$ & $\begin{array}{l}\text { Зелений: > } 90 \text { \% } \\
\text { Бурштиновий: 80-90 \% } \\
\text { Червоний: <80 \% } \\
\text { Сірий (не класифрікований) }\end{array}$ & $\begin{array}{c}5 / 22(22,7 \%) \\
7 / 22(31,8 \%) \\
10 / 22(45,5 \%) \\
0(0,0)\end{array}$ & $\begin{array}{l}8 / 22(36,4 \%) \\
2 / 22(9,1 \%) \\
7 / 22(31,8 \%) \\
5 / 22(22,7 \%)\end{array}$ & $83,0 \pm 8,0$ & $75,8 \pm 10,3$ \\
\hline $\begin{array}{l}\text { IP3 2. Утримання } \\
\text { пацієнта під } \\
\text { наглядом }\end{array}$ & $\begin{array}{l}\text { Зелений: >85 \% } \\
\text { Бурштиновий: 75-85 \% } \\
\text { Червоний: <75 \% }\end{array}$ & $\begin{array}{c}8 / 22(36,4 \%) \\
11 / 22(50,0 \%) \\
3 / 22(13,6 \%)\end{array}$ & & \multicolumn{2}{|c|}{$85,3 \pm 7,6$} \\
\hline $\begin{array}{l}\text { IP3 3. Безперерв- } \\
\text { ність поставок } \\
\text { антиретровірусних } \\
\text { препаратів }\end{array}$ & $\begin{array}{l}\text { Зелений: } 100 \text { \% } \\
\text { Червоний: } 0 \text { \% }\end{array}$ & $\begin{array}{c}20 / 22(90,9 \%) \\
2 / 22(9,1 \%)\end{array}$ & $\begin{array}{c}21 / 22(95,5 \%) \\
1 / 22(4,5 \%)\end{array}$ & $\begin{array}{l}\text { не перерахо- } \\
\text { вується }\end{array}$ & $\begin{array}{c}\text { не перерахо- } \\
\text { вується }\end{array}$ \\
\hline $\begin{array}{l}\text { IP3 4. Практика } \\
\text { призначення } \\
\text { моно- або бітерапії }\end{array}$ & $\begin{array}{l}\text { Зелений: } 0 \text { \% } \\
\text { Червоний: > } 0 \text { \% } \\
\text { Сірий (не класифікований) }\end{array}$ & $\begin{array}{l}22 / 22(100 \%) \\
0(0,0) \\
0(0,0)\end{array}$ & $\begin{array}{c}17 / 22(77,3 \%) \\
0(0,0) \\
5 / 22(22,7 \%)\end{array}$ & 0 & 0 \\
\hline $\begin{array}{l}\text { IP3 5. Вірусологіч- } \\
\text { на супресія }\end{array}$ & $\begin{array}{l}\text { Зелений: >85 \%; } \\
\text { Бурштиновий: 70-85 \%; } \\
\text { Червоний: <70\% } \\
\text { Сірий (не класифікований) }\end{array}$ & $\begin{array}{c}0(0,0) \\
1 / 22(4,5 \%) \\
21 / 22(95,5 \%)\end{array}$ & $\begin{array}{l}7 / 22(31,8 \%) \\
4 / 22(18,2 \%) \\
6 / 22(27,3 \%) \\
5 / 22(22,7 \%)\end{array}$ & $26,9 \pm 9,5$ & $52,6 \pm 12,1$ \\
\hline
\end{tabular}

цієнтів; у третині 303 (в 7 з 22 - 31,8\%) - своєчасно приходили за ліками 80-90 \% пацієнтів) і тільки 5303 з $22(22,7 \%)$ досягли цільового показника (тобто більше 90 \% дорослих пацієнтів у вказаний проміжок часу отримували АРВП). Що стосується дітей, то 8 закладів 322 $(36,4 \%)$ досягли цільового показника (своєчасно отримували препарати більше 90 \% дітей); у 2 (9,1\%) - вчасно приходили за ліками 80-90 \% дітей; у 7 (31,8 \%) - у визначений час отримували АРВ-препарати менше 80 \% дітей. Своєчасність отримання ліків є мірою дисциплінованості пацієнта. Низький рівень цього індикатора, як правило, означає пропущені часи прийому та дози препаратів, а також перерви у лікуванні - все це призводить до ризику формування МР ВІЛ. Основними причинами несвоєчасного отримання пацієнтами АРВ-препаратів можуть бути низька особиста мотивація; недостатнє освідомлення щодо необхідності лікування; зловживання алкоголем та психотропними речовинами; відсутність підтримки з боку близького оточення; недостатній рівень соціально-психологічного супроводу з боку неурядових організацій; незручний час видачі АРВ-препаратів або незручне територіальне розташування 303.

Проте найгіршою виявилася продуктивність більшості закладів по індикатору IP3 5 («вірусна супресія»
- зниження рівня вірусного навантаження ВІЛ менше 1000 РНК-копій/мл), оскільки цільового показнику по дорослим пацієнтам (наявність вірусної супресії у більш ніж 85 \% пацієнтів) не досягнуто в жодному 303. Справа в тому, що при аналізі вказаного IP3 враховується не тільки рівень вірусного навантаження ВІЛ, але й терміни обстеження пацієнтів. Згідно з клінічними протоколами $[8,9]$, рівень ВН ВІЛ у пацієнтів, які отримують АРВтерапію, має визначатися кожні 6 міс., для чого з різних джерел фрінансування закупаються відповідні тести. Тести з обмеженим терміном придатності повинні надходити двічі на рік (за грасріком), проте існуюча в Україні практика державних закупівель $€$ такою, що весь річний обсяг тест-систем (у тому числі з обмеженим терміном придатності) надходить в IV кварталі поточного року. Одночасне надходження річного обсягу тестсистем з обмеженим терміном придатності призводить до того, що тести швидко використовуються на початку року, проте в кінці року - вони відсутні, і це не дозволяє забезпечити дворазову протягом року кратність обстеження пацієнтів. Так, у 2014 р. тест-системи, закуплені в Україні для визначення рівня вірусного навантаження ВІЛ, закінчилися у червні. Оскільки наступна закупівля відбулася лише у грудні 2014 р., а постачання - у бе- 
резні 2015 р., протягом майже 8 міс. моніторинг вірусологічної ефективності АРТ в Україні не проводився. Тому більшість пацієнтів 303, по яким збиралися дані для IP3 5, не мали в анамнезі даних щодо рівня вірусного навантаження ВІЛ через 12-15 міс. лікування та були обстежені значно пізніше.

\section{Висновки}

1. Важливим досягненням у напрямку запобігання фрормуванню медикаментозної резистентності ВІЛ $€$ відсутність в Україні практики призначення антиретровірусних препаратів у вигляді моно- або бітерапії.

2. Вагомим недоліком у роботі $303 є$ низька продуктивність більшості закладів з утримання ВІЛ- інфрікованих пацієнтів на АРТ та щодо своєчасност отримання пацієнтами АРВ-препаратів.

3. Потребує покращення існуюча в Україні практика закупівлі лікарських засобів для АРТ і реагентів для проведення досліджень 3 визначення рівня вірусного навантаження ВІЛ.

4. Впровадження щорічного моніторингу IP3 в закладах охорони здоров'я, які надають АРТ в країні, допоможе своєчасно виявляти та вирішувати проблемні питання в системі надання послуг з АРТ, асоційовані 3 ризиком формування МР ВІЛ, як на рівні окремих закладів, так і на національному рівні.

\section{Література}

1. ВІЛ-інсрекція в Україні // Інформаційний бюлетень. - Київ. 2016. - № 45. - 152 c.

2. 90-90-90: An ambitious treatment target to help end the AIDS epidemic. Geneva: UNAIDS; 2014. Available at: http://www.unaids. org/sites/default/files/media_asset/90-90-90_en_0.pdf

3. World Health Organization. HIV drug resistance early warning indicators. World Health Organization indicators to monitoring HIV drug resistance prevention at antiviral treatment sites (http:// www.who.int/ hiv/pub/meetingreports/ewi_meeting_report/en/index.html)

4. Аналіз індикаторів раннього попередження формування резистентності ВІЛ до антиретровірусних препаратів в Україні / Н.М. Нізова, М.Г. Люльчук, Ю.В. Кобища, К.В. Воронова // Туберкульоз, легеневі хвороби, ВІЛ-інфекція. -2013. - № 1 (12). - С. 14-24.

5. Update on World Health Organization HIV Drug Resistance Prevention and Assessment Strategy: 2004-2011 / M.R. Jordan,

\section{References}

1. VIL-infektsiia v Ukraini [HIV infection in Ukraine]. (2016). Informatsiinyi biuleten [Newsletter]. Kyiv [in Ukrainian].

2. 90-90-90: An ambitious treatment target to help end the AIDS epidemic. (2014). Geneva: UNAIDS. Retrieved from http://www.unaids. org/sites/default/files/media_asset/90-90-90_en_0.pdf

3. World Health Organization. (2010). World Health Organization indicators to monitor HIV drug resistance prevention at antiretroviral treatment sites. June 2010 update.

4. Nizova, N.M., Liulchuk, M.H., Kobyshcha, Yu.V., \& Voronova, K.V. (2013). Analiz indykatoriv rannoho poperedzhennia formuvannia rezystentnosti VIL do antyretrovirusnykh preparativ $v$ Ukraini [Analysis of the data received in the process of HIV drug resistance early warning indicators (EWIs) collection in Ukraine]. Tuberkuloz, lehenevi khvoroby, VIL-infektsiia - Tuberculosis, Pulmonary Diseases, HIV Infection, 1 (12), 14-24 [in Ukrainian].

5. Jordan, M.R., Bennett, D.E., Wainberg, M.A., Havlir, D., Hammer, S. Yang, C. ... Bertagnolio, S. (2012). Update on World Health Organization HIV Drug Resistance Prevention and Assessment Strategy: 2004-2011. Clinical Infectious Diseases, 54, 245-249. doi:http:// dx.doi.org/10.1093/cid/cis20.

6. World Health Organization. (2012). Using early warning indicators to prevent HIV drug resistance. Report of the Early Warning

D.E. Bennett, M.A. Wainberg [et al.] // Clin. Infect. Dis. - 2012. - Vol. 54, N 4. - S245-S249. http://dx.doi.org/10.1093/cid/cis20.

6. http://www.who.int/hiv/pub/meetingreports/ewi_meeting_report/ en/ (appendix 8).

7. WHO. World Health Organization HIV DR EWI tool [internet]. Geneva, World Health Organization. [cited 2015 Sep 15]. Available from: http://www.who.int/hiv/pub/meetingreports.

8. Клінічний протокол антиретровірусної терапії ВІЛ-інорекції у дорослих та підлітків, затверджений Наказом МОЗ України від 12.07.2010 p. №551.

9. Унісрікований клінічний протокол первинної, вторинної (спеціалізованої), третинної (високоспеціалізованої) медичної допомоги «Профрілактика передачі ВІЛ від матері до дитини», затверджений Наказом МОЗ України від 16.05.2016 р. № 449 (у редакції наказу МО3 02.07.2016 №655).
Indicator advisory panel meeting (11-12 August 2011). Retrieved from http://www.who.int/hiv/pub/meetingreports/ewi_meeting_report/en/

7. World Health Organization. (2016). Global report on early warning indicators of HIV drug resistance. Technical report (July 2016). Retrieved from http://www.who.int/hiv/pub/drugresistance/ ewi-hivdr-2016/en/

8. Klinichnyi protokol antyretrovirusnoi terapii VIL-infektsii u doroslykh ta pidlitkiv [Clinical protocol for antiretroviral therapy of HIV infection in adults and adolescents]. Nakaz MOZ Ukrainy vid 12.07.2010 r. №551 - Order of the Ministry of Health of Ukraine № 551, 12/07/2010 [in Ukrainian].

9. Ministerstvo okhorony zdorovia Ukrainy. (2016). Unifikovanyi klinichnyi protokol pervynnoi, vtorynnoi (spetsializovanoi), tretynnoi (vysokospetsializovanoi) medychnoi dopomohy «profilaktyka peredachi VIL vid materi do dytyny» [Unified clinical protocols of primary, secondary (specialized), tertiary (highly specialized) medical care «prevention of HIV transmission from mother to child»]. Nakaz MOZ Ukrainy vid 16.05.2016 r. №449 (u redaktsii nakazu MOZ 02.07.2016 №655) Order of the Ministry of Health of Ukraine №449 16/05/2016 (in the updated version $\mathrm{MOH}$ №655, 02/07/2016)] [in Ukrainian]. 


\section{IMPLEMENTATION OF UPDATED SYSTEM OF EARLY-WARNING INDICATORS OF HIV DRUG RESISTANCE IN UKRAINE}

\section{M.H. Liulchuk}

State institution «L.V. Hromashevskyi Institute of Epidemiology and Infectious Diseases of NAMS of Ukraine»; State institution «Public Health Center of the Ministry of Health of Ukraine» Kyiv, Ukraine

SUMMARY. This was a cross-sectional analysis of retrospectively collected data from 22 AIDS centers providing antiretroviral therapy (ART) to HIV-infected adults and children.

The aim of the work - to evaluate the performance of institutions on the effectiveness of the formation in patient adherence to treatment (on time antiretroviral drugs $(A R V D)$ receipt,) as well as the quality of program factors (retention in care, pharmacy ARVD stock-outs, practice of prescription of mono- or bitherapy, and Viral load (VL) suppression).

Materials and Methods. Data was analyzed using an electronic tool developed by the World Health Organization (WHO) - Early Warning Indicators Drug Resistance (HIVDR EWI).

Results. During 2014-2015 22.7 \% of sites providing adult and $36.4 \%$ of sites providing pediatric ART managed to meet the target for on time pill pick up. Retention in care indicator was met by $36.4 \%$ (95\% Cl: 26.1-46.7) of sites. ARV stock-outs occurred in $9.1 \%(95 \% \mathrm{Cl}$ : 3.0-15.2) adult sites and $4.5 \%$ (95\% Cl: 4.1-8.9) pediatric sites. Only $31.8 \%$ (95\% Cl: 20.5-43.1) pediatric sites and $0 \%$ adult sites reported target for VL suppression HIV at 12 months ART.

Conclusion. Implementation of the annual collection and analysis HIVDR EWI in all ART sites of Ukraine will prevent the risk of the emergence of HIVDR.

Key words: early warning indicators of HIV resistance (HIVDR EWI); antiretroviral therapy (ART); HIV drug resistance (HIV DR).

\section{Відомості про автора:}

Люльчук Марія Геннадіївна - кандидат медичних наук, старший науковий співробітник лабораторії молекулярної вірусології ду «Інститут епідеміології та інфекційних хвороб ім. Л.В. Громашевського Національної АМН України»; лікар-вірусолог дУ «Центр громадського здоров'я МО3 України»; mliulchuk@gmail.com

Information about author:

Liulchuk Mariia - Ph.D., Senior Researcher of the Laboratory of Molecular Virology of State Institution «L.V. Hromashevskyi Institute of Epidemiology and Infectious Diseases of NAMS of Ukraine»; virologist of State Institution «Public Health Center of the Ministry of Health of Ukraine», Kyiv, Ukraine; mliulchuk@gmail.com

Консрлікт інтересів: немає.

Authors have no conflict of interest to declare.

Отримано 23.01.2017 p. 